Vantage: Journal of Thematic Analysis

ISSN: 2582-7391

A Multidisciplinary Publication of Centre for Research,

Maitreyi College, University of Delhi

April 2020, Volume 1, Issue 1

Original Research Article

\title{
Social Media and the Mobilization of Collective Action on Sexual Violence against Women: A Case Study of the ‘\#MeToo’ Movement in India
}

\author{
Madhulika Sonkar ${ }^{* 1}$, Ishita Soorma and Sreshtha Akanksha \\ Department of Sociology, Maitreyi College, Chanakyapuri, New Delhi \\ "Correspondence: madhulika.sonkar@gmail.com
}

\begin{abstract}
This paper aims to understand the role of social media in furthering the movement against and conversations about sexual harassment. By exploring the narratives and responses of young women in Indian metropolitans after the widely popular \#MeToo campaign, this paper attempts to examine the role of social media sites such as Twitter, Instagram and Facebook in rallying the women's rights movement in India. It is a follow up to understand the impact of the \#MeToo campaign that emerged in the West encouraging women globally to recount and speak up against experiences of sexual harassment and rape. What does 'MeToo' signify for women in India?
\end{abstract}

Key words: Gender; India; MeToo; sexual violence; social media

\section{INTRODUCTION}

"It was my usual bus ride to the college in Chanakyapuri from Punjabi Bagh. I was rushing for the morning class and managing a quick glimpse of the class notes when a man stood next to where I was seated. He leaned closer as the bus grew crowded ... eventually rubbing his private part over my right shoulder. I constantly gave him frowned looks, but he signalled the passengers were pushing him. My bus stop was inching closer. Raising my voice would have created commotion, I thought to myself ... Within minutes, I hurried to de-board for the college bus stop, like every other day."

\section{Radhika, Delhi University student}

As young women who made their way to Delhi University, we were left in deep disgust when one of our classmates narrated this incident, she encountered on an early morning bus ride to

\footnotetext{
${ }^{1}$ Madhulika Sonkar current affiliation: Department of Sociology, Indraprashtha College for Women, University of Delhi
} 
college. We could relate to it, even as the bus was replaced by metro or the street. Making our way to a girls' college is often seen as a comforting factor for family and friends. Aspects of safety and security for girls are paramount to parents while seeking educational facilities for the girl child in India. It is important to note, however, that what we experience outside the institution often ends up being a private encounter due to hesitation or fear of shame and honour. While laws and institutional mechanisms remain in place, studies have shown that women refrain from sharing experiences of sexual harassment to protect family honour and dignity, also referred to as 'izzat' in the Indian context. This is common to what women across diverse age groups experience in context of harassment and violence.

In early 2018, as students engaging with the discipline of sociology in everyday lives, we noticed a slow but steadily rising movement on social media sites. We observed women openly coming out with how they were sexually harassed in public transportation; at workplace; in institutions; within the family, and so on. Popular social media platforms such as Twitter, Facebook and Instagram were immersed with such 'stories' that women from different parts of the world shared about men known to them, and strangers to them.

At first, it shook us for the discomfort and ripples it created within the virtual world. This discomfort reached us in real lives when the movement crossed boundaries and reached India. Hashtagged "MeToo", the proportion of women speaking up grew. It was not just about sheer numbers, but more importantly, an indication of how a movement against silence was percolating through our society. Being 'silent' about having experienced harassment in some form or the other is a characteristic of girls' socialization, as we know it.

Propelled from the 'MeToo' movement on the internet, women began to do what was considered 'inappropriate' for them: raise their voice and name the perpetrator. It all began when rape and sexual harassment charges were levelled against Harvey Weinstein, a famous Hollywood producer. Since October 2017, the movement picked pace as more and more women shared their experiences, the internet, particularly social media, was flooded with experiences narrated under the hashtag 'MeToo'.

Actress Alyssa Milano started the hashtag 'MeToo' on twitter to bring together victims of sexual violence after which the hashtag spiralled into a wider rally for speaking up against sexual violence. The original 'MeToo' phrase was started by New York based activist Tarana Burke in 2006 after she was inspired by a 13-year old girl who confided in her to share her sexual assault experience, to which she replied 'MeToo' (Murphy, 2019). The hashtag trended in at least 85 countries as the movement spread across the world: from Britain's Westminster scandal to Australia's Weinstein Don Burke and journalist Shiori Ito's 
unprecedented public discussion about her alleged rapist in Japan. In Spain, it became \#yotambien, in France it became \#balancetonporc, in Italy \#quellavoltache etc. In India, Bollywood actresses Konkona Sen Sharma and Radhika Apte came out in support of \#MeToo movement in India.

For us, as sociology students, the movement raised questions that we seriously wanted to ponder over as young women in India. This paper is an effort in that direction. We intend to move beyond the ripples that the movement has created on social media and beyond it. The important question is: has the 'MeToo' movement steered change in attitudes, beliefs and the 'culture of silence' in context of experiences of sexual harassment?

What does 'MeToo' signify for women in India? This paper aims to understand the role of social media in taking ahead conversations about sexual harassment. By exploring the narratives and responses of young women in Indian metropolitans after the \#MeToo campaign, this research attempts to examine the role of social media (mainly Twitter, Instagram, and Facebook) in rallying the women's rights movement in India. It is a follow up to understand the impact of the \#MeToo campaign that emerged in the West encouraging women globally to recount incidents of sexual harassment and rape on public platforms.

\section{METHODOLOGY}

The research work for this paper is primarily focused on reaching out to women from metropolitans. We chose the survey method to cover a series of questions based on women's experiences and views pertaining to the 'MeToo' movement. A sample size of 60 women in the age group of 18-25 years was chosen in Delhi for an online survey. In addition to the surveys, we engaged in data collection on social media to understand the kind of experiences that were shared by women under the 'MeToo' movement in India. The questionnaire focused on the following issues:

- Level of awareness among Delhi women about this global movement

- Perceptions associated with impact and change brought about by the campaign

- Individual experiences of harassment and violence

- Role of internet in sensitizing society about gender equality

\section{RESULTS}

The analysis of the survey that we conducted amongst 63 women in the age group of 18-25, living in urban areas and who are socially active, was that $89 \%$ women were aware of the \#MeToo movement whereas $11 \%$ expressed not hearing about the movement (Figure 1). According to the data we collected, this movement was more effective and viral in the 
developed countries like US, Japan etc. as compared to India. Even in India, the effectiveness has varied as the movement has not gone viral homogeneously and this is one of the reasons that $11 \%$ of the women replied to the question in the survey in pure ignorance. This is when globally, over 1.7 million tweets in 85 countries included the hashtag "\#MeToo" (Park, 2017). On asking about their views on the \#MeToo movement, the terms used by women included 'empowering', 'courage', 'bravery', 'bold' thereby indicating that it has helped women come forward with their experiences without being ashamed. At the same time, it created a sense of togetherness and belonging and thus gave them a platform to ' break their silence'.

In the Indian context, $22.2 \%$ of the interviewers thought that the movement has led to some changes for women. According to them, \#MeToo movement provided a platform to voice out their views and experiences in public and a sense of togetherness, boldness, and a feeling of being supported and not being the only one. Over 20 percent women also think that this movement has brought about no changes for women in India specially in the poorer sections, as they are still scared to report abuse fearing blame and backlash. Additionally, they also think that the mental and social attitudes regarding the women in the society are still the same.

Majority of the interviewers i.e. 55.6\% women think that the movement has, maybe, brought about changes to some extent in India. The reason for this dilemma is possibly that the rate of sexual harassment has not quite gone down; no major changes can be seen in the society. According to the survey conducted, $85.7 \%$ respondents have not shared their experiences of sexual harassment or sexual violence ever on social media. While on the other hand, $14.3 \%$ claim to have done it as part of the 'MeToo' movement. A feeling of discomfort and selfconsciousness while sharing something so intimate about their personal lives in public has been prevalent in the respondents' views.

Complementing the survey analysis, our analysis of media reports shows that it has been mostly the celebrities and famous personalities who have gathered greater media attention through such movements. It can also be inferred that some interviewers think that sexual harassment is a problem of the entire country, affecting women irrespective of their status.

\section{DISCUSSION}

\subsection{The voices}

We use these narratives as voices of women that attempt to challenge patriarchal setups and norms. These are some of the real-life experiences shared by women on social media as part of the \#MeToo movement. We present the narratives in their original form to maintain the power of voices of women who asserted themselves in the movement. 
- Had a cardiologist- who was my employer - trap me inside an office, locked the door, and whipped his penis out for me to touch it. Paralyzed initially, I knew I had to get out of the room because I was the only person in the entire building. I became angry, demanded that he unlock the door, and then I threatened him that he would lose his medical license. He thought that he could slip me a $\$ 100$ bill to keep my mouth shut.

- When I was 18 , I was tricked to go to a swimming pool area at night by a "trusted head lifeguard". He took me into the shower room area for a mini-tour and I noticed an entire camera with tripod setup behind one of the stalls. My intuition told me to leave. I found out later, he takes girls there to videotape them while having sex with them. He was the son of a powerful egoistical prominent lawyer. And these are only the ones that immediately spring to mind. Used to feel too embarrassed to admit this, so I can totally understand why people would not come forward, but it is not my/our fault, I/we did not do anything wrong. And even though I/we are not necessarily damaged by these things, that still does not make them acceptable. The VEIL is being lifted as the patriarchal mechanism that evokes MALE DOMINANCE over women is being brought forth to the light now. Everything is coming into balance and the Universe is doing its own internal karmic cleansing. THE FEMININE RISES.

- As a 16-year-old girl attending one of those massive parties, organized by teenagers, for teenagers. Looking back, I had no business being in a farmhouse with such less security and that much alcohol. I was stepping out of the bathroom, when an older man entered and pushed me back inside. My memory is hazy - but I managed to shove my way out within a few minutes. I spent the rest of the evening in tears, being consoled by my friends. That guy was immediately located and made to leave the premises. But he should have been reported to the police. Even that slight brush with such an incident made me feel mentally weak - I spent the rest of the week randomly breaking down in tears.

- Was working at a client field when an elderly man came behind and hugged me. My manager said it was not a big deal \#MeToo

- Crowded tram at Disney, sat a row behind my family. Man kept his hand on my thigh the whole ride, stroking the fine hair there. His friend looked on. Think I was 11 but scared to confirm dates of that trip with my mom, because I never told anyone. Us too. All of us.

- I was in 2nd year of graduation at Gargi College. I had just finished band practice and decided to walk across and wait for an auto rickshaw - back in 2009, Uber and Ola were not even in the running. This was around 3 or $4 \mathrm{pm}$ when the Siri Fort road area would get strangely deserted. While I waited, a car stops just a little ahead of where I was standing. 
He backs up his car to me and asks me to get in, with a slight nod of his head. I did not really know what was happening. Was I supposed to know this man from somewhere? Was he a family friend I had met some long time ago? I'm usually very good with faces and this man brought back no recollection, whatsoever. I asked him if he needed help with directions. He laughed, amused. I still did not understand what was going on. 'You're a college girl, aren't you?" he asked me; the smirk was still plastered across his face. I nodded, not knowing what else to do. "Would you like to volunteer for the Commonwealth Games?" he asked. Yes, that was the time when the capital was prepping for one of the most historic events in the country and college students were clammering to get brownie points on their portfolios by being even a remote part of the event. "Why do you ask?" I countered his question. "Because I can give you work," he retorted, still smiling in a way that starts turning uncomfortable almost as if he knew what was about to happen and I did not. "I'll take you to my hotel room and explain what work you need to do." I was baffled, to say the least. I still did not know what was going on; more so because I realise things late and because such a thing had never happened before. "Kyun, dar gayi?" he asked in Hindi. "Ladki ho ke aise bra pehenti ho aur dar gayi?"- I was wearing a halter inside with a fully covered black t-shirt and a pair of jeans, by the way. He still noticed the thin strap around my neck when that was literally the only part of my body that was revealed. I somehow, managed to gather my wits, asked him to kindly drive on after mustering a meek voice to reply, 'No, thank you' to the man's 'generous' offer. He went ahead and stopped, and I stood hoping an auto-rickshaw would come by. One did. He asked for an exorbitant amount of fare because the meters were literally only an object back then. I never hesitated once and told him to drive at lightning speed.

- It happened during my school summer holidays. I was around 11 years old and my parents had taken me and my elder sister to Mumbai for the vacations. We even had a wedding to attend in between all the sightseeing and the weekend trip to Goa. It was there at the wedding that my worst nightmare came true. And I do not have any hazy memories about it. It is all crisp and clear in my mind to this day. An acquaintance of my father must be easily around 45 years old came and started chatting with me about my studies. Uncle, as I referred to him was sweet and had a bag full of candies to offer. May I also tell you that the gathering was that of a high-ranking official who we would normally refer to as the high society. Not the regular shady men you spot on the streets all the time. The uncle then grew extremely interested in my knowledge about computers and asked me to take a walk with him while I boasted about my computer skills. Before I knew it, we were in a secluded corner of the 
venue and he grabbed me by the waist and kissed me on my mouth. I was too young to know what had just happened. I felt uneasy but I did not know what to do. Next, he started fiddling with my barely- there breasts. That is when I knew something was totally wrong and told him I needed to pee. We were taught not to be rude to elders and I was still being respectful while he followed me to the loo. He tried to come inside the cubicle but luckily my sister was right there, and he had no choice but to back off. It was only a couple of years later that I realized what had happened. That man even came visiting us few years back and I excused myself out of the house before he arrived. Till date, I have not got the courage to tell my parents. I probably do not want to. I probably just want to let it go... Because the truth is, I do not even know his name, how do I even tell my parents who was at fault.

\subsection{Interpretation}

The \#MeToo movement must be recognised as a powerful wave in the history of feminist movements and struggle for gender equality. Within 3 months of its beginning, there were 2.3 million tweets and over 77 million posts or comments on Facebook (Murphy, 2019). Social media thus played a vital role in spreading of this movement worldwide in a short span of time. However, not everyone's \#MeToo story got the same amount of spotlight and a significant criticism of the movement has been its inability to leave certain people behind. The polarised coverage of the movement is also something we want to focus on. International coverage of \#MeToo in the US has focussed only on the West. South Asia has been largely missing from the impact of the movement. \#MeToo movement has been an eye-opening campaign but it also runs the risk of losing direction if social media sites and its users become more dominant as it's megaphone to the masses.

In the media industry, male journalists have been shaping the news articles and journals from a male point of view leaving behind the details from a woman's point of view which further reaches the world. It was also visible through the social media networking sites that men were even scared of the false accusations and therefore the relation between male and female coworkers loosened and their bond weekend especially at the workplace.

Our data suggests that awareness associated with sexual harassment and violence should be inculcated right from the school. The study emphasises that movements like these can be the backbone of a future revolution to end the injustice, but for that to happen these movements should not be only restricted to social media as majority of the people in developing countries or third world countries do not have access to the internet. Debates and talk shows on news channels regarding the same should be held. Events should be organised in urban poor 
settlements and the disadvantaged section of the society and rural settlements for people who do not have access to the aforementioned sources.

Even as it is still debated whether the changes will be in the favour of the women or not as the men can also feel insecure by working near women as they can frame them because of some personal agenda. But the women after the movement have started to ask questions which they never asked before. The movement has helped abuse survivors seek support. Increase in the use of online helpline service was seen in many countries. For long lasting effect of the movement, policies must be implemented accordingly, or else the campaign will go cold like all the others in the past.

\section{CONCLUSION}

This paper attempted to address some complexities found in the ways in which the \#MeToo movement shaped women's lives in India. First, the study points out the widespread nature of sexual harassment and abuse across diverse locations and spaces. The notion of justice and gender equality also occurs as themes central to women's concerns after they participated in the \#MeToo movement. With methodological constraints of time and reach, this study has attempted to present a view of the impact of collective mobilisation through social media for gender movements.

\section{CONFLICT OF INTEREST}

None

\section{SOURCE OF FUNDING}

The project was funded by Maitreyi College, University of Delhi under the Summer Internship Program.

\section{ACKNOWLEDGEMENT}

Our sincere thanks are to the faculty of the Department of Sociology and to the Principal, Maitreyi College, University of Delhi for giving us this opportunity to carry out the research on this particularly important issue.

\section{REFERENCES}


Ali, A. "61 Indian academics on crowd-sourced list of 'harassers'". Indian Express. October27, 2017. https://www.indianexpress.com/article/india/61-indianacademics-on-crowdsourced-list-of-harassers-4908459/lite/

Bansode, R. (2020). The Missing Dalit Women in Testimonies of \#MeToo Sexual Violence: Learnings for Social Movements. Contributions to Indian Sociology. 54(1): 76-82. https://doi.org/10.1177/0069966719885563

Menon, N. "How the feminist conversation around sexual harassment has evolved". Feb28, 2019. https://www.thewire.in/article/women/how-the-feministconversation-aroundsexual-harassment-has-evolved/amp

Murphy, M. (2019). Introduction to "\#MeToo Movement", Journal of Feminist Family Therapy, 31(2-3): 63-65, DOI: 10.1080/08952833.2019.1637088

Park, A. "Me too reaches 85 countries with 1.7 million tweets." CBS News, 24 October 2017. www.cbsnews.com/news/metoo-reaches-85-countries-with-1.7-million-tweets/

Roy, S. (2018). \#MeToo Is A Crucial Moment to Revisit the History of Indian Feminism. Economic and Political Weekly. 53(42): 6-12.

How to cite this article: Sonkar, M., Soorma, I. \& Akanksha, S. (2020). Can Social Media Mobilise Collective Action for Sexual Violence Against Women?: A Case Study of the ‘\#MeToo’ Movement in the Context of India. Vantage: Journal of Thematic Analysis, 1(1), 6674.

DOI: https://doi.org/10.52253/vjta.2020.v01i01.07

(C) The Author(s) 2020.

This work is licensed under a Creative Commons Attribution 4.0 International License which permits its use, distribution and reproduction in any medium, provided the original work is cited. 